\title{
Improving The Performance of Local Manufactured Paperboard
}

\author{
Mona A. Nassar*, S. Ibrahim , M. Attia and Y. Refaat \\ Packaging and Packaging Material Department,National Research Centre, Elbehoth \\ Street 33, 12622, Dokki, Cairo, Egypt.
}

$\mathbf{H}$ GH strength and environmentally friendly packaging paperboard is currently asked in industry. The present workis focused on preparing paperboard from rice straw pulpapplying acetic acid / water mixture to cook rice straw. Three ratios of acetic acid namely $30,40,50 \%$ were used at $140 \mathrm{C}^{0}$ for $90 \mathrm{~min}$. The strength of the produced pulp was weak and was not enough to meet the challenges of industrial packaging. So, rice strawas virgin pulp was blended with recycledduplex paperboard by different percentage and top layer of wood pulp to give paperboard of basis weight $280 \mathrm{~g} / \mathrm{cm}^{2}$. The blended ratios were $10 \%, 20 \%$ and $30 \%$ rice straw pulp and $90 \%, 80 \%$ and $70 \%$ recycled duplex. $10 \%$ rice straw pulp gave better results more than $20 \%$ and $30 \%$ in the blended paperboard .In addition coating with the three local pigments, ground calcium carbonate, titanium dioxide and kaolin on one surface of paperboard was applied and investigated.Commercial resin was also used to coat paperboard surface and compared with the local pigments. These tow treatments namely blending and coating for rice straw pulp gained paperboard with good mechanical properties in both machine direction and cross direction.

Keywords: Paperboard, Rice straw, Pulping, Coating, Natural pigments.

\section{Introduction}

Using of agro residues, which is the key source of non-wood fibers in pulp and paper production, has shown an increasing trend in recent times due to ecological consideration as they prevent the deforestation[1]. It is also well known that nonwood materials can be delignified more easily than wood bark under alkaline conditions [2]. The severe depletion of forest raw material and the growth of agro-based paper mills have led to increased utilization of agricultural residues and other secondary raw materials which have now assumed a significant role in meeting the demand of cellulose fibers for paper industry. Rice straw pulp can be used in most papers as a substitute for hardwood pulp. Pulp made from straw is best suited for corrugated medium, newsprint, printing and writing papers, and linerboard. Usually paper products are not made from $100 \%$ straw pulp, but are mixed with recycled or wood pulps,[3] and could be mixed with other non-woods. Acetic acid, like most of the organic chemicals[4]used to produce pulp, was originally used to isolate lignin from wood $[5,6]$. In order to make use of rice straw as agricultural wastes effectively and to develop a novel pulping method for rice straw without environmental impact, an atmospheric acetic acid was used as pulping agent [7].

The results indicated that the acetic acid pulping process is a promising method for rice straw. The straw gave screened pulps with favorable strength properties when refluxed in watery $\mathrm{AcOH}$ containing mineral acid as catalyst for 3 hours.[8] .These strength like stiffness and tensile are not enough for packaging paper. Paper surface treatments are thus increasingly used in every paper mill to control and improve the surface, water uptake and mechanical properties of its product. The surface treatments may be physical (calendering) or chemical (surface sizing or coating) $[9,10]$. Extrusion, dispersion coating and solution application are the most fundamental techniques applied to coat polymeric materials on

*Coressponding author e-mail: monanassar_65@yahoo.com

DOI : 10.21608/EJCHEM.2017.3595

(C)2017 National Information and Documentation Center (NIDOC) 
many substrates. These well known techniques, which are considered traditional processes, give wide possibilities to form coated one layer, multilayer and laminated structures. Paperboardbased packaging is widely used because it meets the criteria for successful packing, namely to:

contain the product

protect goods from mechanical damage

preserve products from deterioration

inform the customer/consumer

provide visual impact through graphical and structural design.

This requires among other things that the adhesion of the facing materials, the mechanical properties of each material and the surface friction of the product are adjustable factors. Simultaneously, the performance of the converting product must meet the requirements on costeffectiveness during the manufacture and use, and more often, also during recycling and disposal. Therefore, the relation between cost and function of package must be considered [11].Calcium carbonate, titanium oxide and kaolin are natural pigments and have the advantage of low price. The aim of this study is employing rice straw as agriculture residue waste to produce paperboard. The suitability of manufactured paperboard for efficient packaging and its surface to meet the requirements of good health printing is another purpose. Alexandria company paperboard sample was used for comparison.

\section{Materials and Methods}

\section{Pulping}

Cooking was carried out in cylindrical cup (stainless steel 321) at atmospheric pressure. The rice straw (200 g o .d.), was cut into fragments of an average length of $3.0 \mathrm{~cm}$ was first impregnated in water at room temperature for 48 hours. After impregnation, water was pressed carefully and cooking was carried out under various conditions. The pulp so obtained was filtered, pressed and washed twice with water. It was finally air dried and weighted.

Pulping conditions were:

- Acetic acid concentration: 30\%, 40\%, and $50 \%(\mathrm{v} / \mathrm{v})$

- Catalyst $(\mathrm{HCl})$ concentration: $0.5 \%(\mathrm{v} / \mathrm{v})$

- Temperature: $140^{\circ} \mathrm{C}$

- Cooking time: $90 \mathrm{~min}$

- Liquor to straw ratio: 10/1
Ash and silica analysis

The quantities of ash and silica of the crude pulp were determined. The sample was heated at $450^{\circ} \mathrm{C}$ for $30 \mathrm{~min}$ and $45 \mathrm{~min}$ at $800^{\circ} \mathrm{C}$ in a muffle and the ash amount and ratio weight of ash/weight of the dried material were calculated.

\section{Sheet formation $(165 \mathrm{~mm})$}

The paperboard sheets were prepared according to Tappi standard method using the sheet former AB Lorentzen and Wettre (Stockholm, Sweden). A single layer sheet of $165 \mathrm{~mm}$. diameter, 100g/ m2basis weight and $214 \mathrm{~cm}^{2}$ surface area was formed. After sheet formation, the sheets were pressed for 4 min by means of a hydraulic press at $5 \mathrm{~kg} / \mathrm{cm}^{2}$, and then dried in a rotating cylinder at $120 \mathrm{oC}$ for 2 hours. The sheets were then conditioned at $18-20^{\circ} \mathrm{C}$ and relative humidity of $65 \%$.

\section{Sheet formation $(420 \times 640 \mathrm{~mm})$}

A double layer sheet with (width: 640mm, height: $420 \mathrm{~mm}$ ) was formed on Leaf casting paper machine using two layers. Top layer was formed using virgin wood pulp and second layer formed using recycledduplex blended with rice straw pulp. After two sheet formation, the sheets were pressed for $4 \mathrm{~min}$ by means of a hydraulic press at $5 \mathrm{~kg} /$ $\mathrm{cm}^{2}$, and then dried at room temperature for 48 hour. The sheets were then conditioned at $18-20^{\circ} \mathrm{C}$ and relative humidity of $65 \%$.

\section{Mechanical properties of paperboard \\ Strength properties}

Strength properties were estimated according to the Tappi Standard Methods.

Tensile strength: Tensile strength was conducted according to Tappi standard (T 494 om-01). Tensile index, the tensile strength in N/m divided by grammage.

Stiffness strength: Stiffness was conducted according to Tappi standard (T 489 om-08 ) This procedure is used to measure the stiffness or paper and paperboard by determining the bending moment in gram centimeters necessary to deflect the free end of a $38-\mathrm{mm}$ wide vertically clamped specimen $15^{\circ}$ from its center line when the load is applied $50 \mathrm{~mm}$ away from the clamp.

Taber Stiffness Units are defined as the bending moment of $1 / 5$ of a gram applied to a $11 / 2$ " wide specimen at a 5 centimeter test length, flexing it to 
an angle of $15^{\circ}$. A Stiffness Unit is the equivalent of one gram centimeter.

$$
\mathrm{E}=0.006832 \cdot(1 /(\mathrm{w} \cdot \mathrm{d} 3 \cdot \theta)) \cdot \mathrm{ST}
$$

where $\mathrm{E}=$ Stiffness in flexure in pounds per square inch

$\mathrm{W}=$ specimen width in inches

$\mathrm{D}=$ specimen thickness in inches

$\theta=$ deflection of specimen converted to radians $\left(15^{\circ}=0.2618\right.$ radians, $7.5^{\circ}=0.1309$ radians $)$

\section{Coating preparation}

The basic coating formula used in this study consisted of 133 pph of pigment 60 pph binder. Selected pigments for paperboard coating application were $\mathrm{CaCO}_{3}$, Kaolin and $\mathrm{TiO}_{2}$; coating mixtures were prepared as following steps: pigment was dispersed in water in a high shear mixer for 20 min at $50 \%$ solid content. The pre-dispersed binder was gradually added, over a five minute period to the pigment slurry; for this step the impeller speed was reduced to moderate speed. Finally, water was added to obtain the desired solid content.

Styrene Butadiene (SB) was provided by BASF for chemical

Titanium dioxide supplied by Zahra chemical company

Calcium carbonate supplied by ASCOM geology \& mining

Kaolin was provided by Emac for paperboard manufacture

\section{Coating viscosity}

The viscosity is the internal friction of fluid caused by molecular attraction; which makes it resistance to flow. It was measured at room temperature $\sim 20 \mathrm{oC}$, using Brookfield viscometer model RDVD-111U U.S.A. This test method is described in ASTM D1084 - 08.

\section{Preparation of coated paperboard samples}

The selected hand sheets were coated on a single side using the wire-wound rod coater mentioned above, and the coating weight was $20 \pm$ $2 \mathrm{~g} / \mathrm{m} 2$. After being dried immediately in a heating oven at $200 \pm 2 \mathrm{oC}$ for $1.0 \mathrm{~min}$, the coated hand sheets were moved into an air-conditioned room at $23 \pm 1 \mathrm{oC}$ and $50 \pm 2 \%$ relative humidity for $24 \mathrm{~h}$, and were then weighed.

\section{Results and Discussion}

\section{Pulping}

The key element for sustainable utilization of the non-wood fibers is to understand their special qualities and how they affect the technical aspects involved. Low bulk density, short fiber and high content of fines are the most important features [12].Other disadvantages include transportation and storage problems; comparatively high silica content; very quick degradation (high losses) [13]. Pretreatments aim at rendering the non-wood fibrous raw materials more suitable for the pulping and papermaking process or even to improve the digestibility of this important lignocelluloses biomass for the production of the biofuel and other value added chemicals.

Rice straw is composed of heterogeneous complex of carbohydrate polymers. In this investigation low temperature (room temperature) water pretreatment of rice straw was used in order to increase lignin dissolution in the subsequent delignification stage. The results obtained from the acetic acid pulping of rice straw under different concentrations are shown in Table 1. In acetosolv pulping, the acetic acid is the main driving force in delignification.

The addition of $\mathrm{HCl}$ as a catalyst in acetic acid pulping of rice straw improved somewhat the delignification process when its charge was $0.5 \%$ volume percentage $(\mathrm{v} / \mathrm{v})$ with respect to the cooking liquor, indicating that $\mathrm{H}+$ is needed to catalyze the salvation of the lignin fragments as shown by others $[14,15]$. It is clear that increasing acetic acid concentration from $30 \%$ to $50 \%$ results in decreasing tensile strength of paperboard made from $100 \mathrm{~g} / \mathrm{m} 2$ ofthe produced pulp.

All strength properties were comparatively inferior to those of conventional pulp. The reason may be the damage of fibers during acidic pulping. Similar results were found in acetic acid pulping of wheat straw. It is assumed that organic acid promotes the salvation of lignin fragments but, at the same time, reduces swelling predominantly

TABLE 1. Effect of acetic acid concentration on mechanical properties of rice straw pulp at $140^{\circ} \mathrm{C}$ for $90 \mathrm{~min}$.

\begin{tabular}{|c|c|c|}
\hline $\begin{array}{c}\text { Acetic acid } \\
\text { concentration }\end{array}$ & $\begin{array}{c}\text { Breaking } \\
\text { length, } \mathbf{m}\end{array}$ & $\begin{array}{c}\text { Tensile } \\
\text { index, Nm/g }\end{array}$ \\
\hline $30 \%$ & 441.25 & 29.43 \\
\hline $40 \%$ & 425.4 & 28.33 \\
\hline $50 \%$ & 365 & 24.39 \\
\hline
\end{tabular}

Egypt. J. Chem. 60, No. 3 (2017) 
of the carbohydrate fibers,[16] which may also be the cause of lower strength properties. Ash-rich epidermal cells remaining in acetic acid pulp can be considered as another reason of lower strength. These non-fiber cells are short and stiff. They have no contribution to the strength of the pulp; instead, they obstruct bonding between fibers.

\section{Blending rice straw pulp and recycled duplex}

Acetic acid rice straw pulp produced by cooking using 30,40,50\% (acid/water) at $140^{\circ} \mathrm{C}$ for 90 minutes under atmospheric pressure was blended with recycled duplex pulp to produce paperboard of basis weight $280 \mathrm{~g} / \mathrm{cm}^{2}$. Physical properties of hand sheets paperboard were illustrated in table 2.The changes of properties varied depending on the blend composition. The blended ratios were $10 \%, 20 \%$ and $30 \%$ rice straw pulp and $90 \%, 80 \%$ and $70 \%$ recycled duplex. It is clear from this table that paperboard produced from rice straw pulp cooked by $30 \%$ acetic acid gives high breaking length and tensile index 2004 m,130 respectively. Also, 10\% rice straw pulp give better results more than $20 \%$ and $30 \%$ in the blended paperboard as shown in Table 2. Rice straw cooked by $40 \%$ (acid/ water) and blended with recycled duplex produce paperboard having lower strength more than the first rice straw pulp as clear from Table 3. Increasing the ratio of rice straw pulp from $10 \%$ to $30 \%$ in paperboard reduced the breaking length and tensile index from $1859 \mathrm{~m}, 123.81$ to $1831 \mathrm{~m}, 119.68$ respectively. This reflects the poor properties of rice straw pulp. Effect of rice straw pulp \% cooked by $50 \%$ acetic acid on mechanical properties of blended paperboard was indicated in Table 4 . The lowest stiffness was obtained from this pulp. The improved values of breaking length and tensile index 1970 m, 2016 m,128 and 131 respectively reflects that recycled duplex enhanced the weak rice straw pulp cooked by this concentration.

\section{Paperboard abbreviation}

- Uncoated paperboard composed of $10 \%$ rice straw pulp cooked by $30 \%$ acetic acid at $140^{\circ} \mathrm{C}$ for 90 minutes under atmospheric pressure and 90\% recycled duplex pulp with wood pulp top layer having a grammage of $280 \mathrm{~g} / \mathrm{m}^{2}(\mathrm{RS} 30 / \mathrm{D})$

- Uncoated paperboard composed of $10 \%$ rice straw pulp cooked by $40 \%$ acetic acid at $140^{\circ} \mathrm{C}$ for 90 minutes under atmospheric pressure and 90\% recycled duplex pulp with wood pulp top layer having a grammage of $280 \mathrm{~g} / \mathrm{m}^{2}(\mathrm{RS} 40 / \mathrm{D})$
TABLE 2. Effect of rice straw pulp \% cooked by $30 \%$ acetic acid on mechanical properties of blended paperboard.

\begin{tabular}{|c|c|c|c|}
\hline $\begin{array}{c}\text { Rice straw } \\
\text { pulp }\end{array}$ & $\begin{array}{c}\text { Stiffness } \\
\text { strength, } \\
\text { g.cm }\end{array}$ & $\begin{array}{c}\text { Breaking } \\
\text { length, } \mathbf{m}\end{array}$ & $\begin{array}{c}\text { Tensile } \\
\text { index,Nm/g }\end{array}$ \\
\hline $\mathrm{RS} 30 / 10 \% \mathrm{D}$ & 100 & 2004 & 130.92 \\
\hline $\mathrm{RS} 30 / 20 \% \mathrm{D}$ & 82.5 & 1800 & 117.6 \\
\hline $\mathrm{RS} 30 / 30 \% \mathrm{D}$ & 90 & 1831 & 119.57 \\
\hline
\end{tabular}

TABLE 3. Effect of rice straw pulp \% cooked by $40 \%$ acetic acid on mechanical properties of blended paperboard.

\begin{tabular}{|c|c|c|c|}
\hline $\begin{array}{c}\text { Rice straw } \\
\text { pulp }\end{array}$ & $\begin{array}{c}\text { Stiffness } \\
\text { strength, g.cm }\end{array}$ & $\begin{array}{c}\text { Breaking } \\
\text { length,m }\end{array}$ & $\begin{array}{c}\text { Tensile } \\
\text { index } \\
\text { Nm/g }\end{array}$ \\
\hline RS40/10\%D & 177 & 1895 & 123.81 \\
\hline RS40/20\%D & 120 & 1869 & 125.20 \\
\hline RS40/30\%D & 70 & 1831 & 119.68 \\
\hline
\end{tabular}

TABLE 4. Effect of rice straw pulp \% cooked by $50 \%$ acetic acid on mechanical properties of blended paperboard.

\begin{tabular}{|c|c|c|c|}
\hline $\begin{array}{c}\text { Rice straw } \\
\text { pulp }\end{array}$ & $\begin{array}{c}\text { Stiffness } \\
\text { strength, } \\
\text { g.cm }\end{array}$ & $\begin{array}{c}\text { Breaking } \\
\text { length, m }\end{array}$ & $\begin{array}{c}\text { Tensile } \\
\text { index } \\
\text { Nm/g }\end{array}$ \\
\hline $\mathrm{RS} 50 / 10 \% \mathrm{D}$ & 97.5 & 1815 & 117.63 \\
\hline $\mathrm{RS} 50 / 20 \% \mathrm{D}$ & 97.5 & 1970 & 128.83 \\
\hline $\mathrm{RS} 50 / 30 \% \mathrm{D}$ & 95 & 2016 & 131.95 \\
\hline
\end{tabular}

- Uncoated paperboard composed of $10 \%$ rice straw pulp cooked by $50 \%$ acetic acid at $140^{\circ} \mathrm{C}$ for 90 minutes under atmospheric pressure and 90\% recycled duplex pulp with wood pulp top layer having a grammage of $280 \mathrm{~g} / \mathrm{m}^{2}$ (RS50/D).

- Coated paperboard composed of 10\% rice straw pulp cooked by $30 \%$ acetic acid at $140 \mathrm{oC}$ for 90 min under atmospheric pressure and 90\% recycled duplex pulp with wood pulp top layer having a grammage of $280 \mathrm{~g} / \mathrm{m}^{2} \quad$ (RS30/DC)

- Coated paperboard composed of 10\% rice straw pulp cooked by $40 \%$ acetic acid at $140 \mathrm{oC}$ for 90 min under atmospheric pressure and $90 \%$ recycled duplex pulp with wood pulp top layer having a grammage of $280 \mathrm{~g} / \mathrm{m}^{2} \quad$ (RS40/DC).

- Coated paperboard composed of 10\% rice straw pulp cooked by $50 \%$ acetic acid at $140^{\circ} \mathrm{C}$ for 90 min under atmospheric pressure and 90\% 
recycled duplex pulp with wood pulp top layer having a grammage of $280 \mathrm{~g} / \mathrm{m}^{2} \quad$ (RS50/DC).

- Uncoated Alexandria paperboard (UP)

- Coated Alexandria paperboard (CP1), Coated Alexandria paperboard (CP2), Coated Alexandria paperboard (CP3)

\section{Characteristics of silica content}

Rice straw used in this study had $17.5 \%$ ash and most of this ash was silica. The ash content was much higher than that of wood (usually less than $1 \%)$. The percentage of silica in ash of rice straw and wheat straw are similar $(17.5 \%, 17 \%$ respectively). Crude pulp produced from cooking rice straw using $30 \%$ acetic acid and $\mathrm{HCl}$ catalyst at $140^{\circ} \mathrm{C}$ for 1.5 hours under atmospheric pressure contain 14.6\% ash content which is lower than that of raw material $17.5 \%$. Whereas, that obtained by pulping using $40 \%$ and $50 \%$ acetic acid under the same pulping conditions contain 19.5 and $19 \%$ ash content respectively which higher than that of raw material $17.5 \%$. This means that cooking of rice straw in a mixture of acetic acid / water cooking liquor results in the retention of silicon derivatives in the pulp. Applying this simple treatment, the ash in the pulp and fines consisted mainly of silica. The silica left in the pulp may function as a filler of paper.

\section{Coating}

Three pigment coatings with different formula were prepared from the commercial grade pigments; $\mathrm{CaCO}_{3}, \mathrm{TiO}_{2}$ and Kaolin. One binder styrene butadiene (SB) was mixed with pigments .The percentage of coating preparation are shown in Table 5. Pigment coating of paperboard is performed to enhance physical properties of paperboard and printability [17].

\section{Coating Viscosity}

Viscosity is a property arising from collisions between neighboring particles in a fluid that are moving at different velocities. It is clear from Table 6 that the three prepared coating solutions of $\mathrm{CaCo}_{3}$, Tio2 and kaolin have the same viscosity parameters.

\section{Paperboard coating}

Paperboard prepared by Leaf casting paper machine in A4 size having basis weight $280 \mathrm{~g} / \mathrm{m} 2$ was investigated. Paperboard composed of $10 \%$ rice straw pulp and $90 \%$ recycled duplex pulp covered by wood pulp was selected to study the characteristics of uncoated and coated blended paperboard. Tensile strengthand stiffness were measured along machine direction and cross direction. It is noticeable that mechanical properties as breaking length and stiffness of paperboard prepared by this machine differs from those handmade sheets prepared according to Tappi standard method. In general the overall mechanical properties are lower. For example, A4 paperboard composed of $10 \%$ rice straw pulp cooked by $30 \%$ acetic acid and 90\% recycled duplex have breaking length value $1172 \mathrm{~m}$, whereas the handmade Tappi sheet have $2004 \mathrm{~m}$ breaking length value. Regards to the measurements along machine directions and/ cross directions, Table 6 indicates that mechanical properties of A4 paperboard measured along cross direction are lower than those measured along machine direction. For uncoated paperboard, the stiffness and tensile strength along machine direction (MD) are higher compared to the cross-direction (CD) due to anisotropy of the paperboard web. Also, it is found that mechanical properties of this A4 paperboard is lower than that obtained from Alexandria company (blank).

Paperboard was coated by three different coatings with coating weight $20 \mathrm{~g} / \mathrm{cm}^{2}$.Physical properties of one surface coated paperboard sheets were illustrated in Tables7,8,9,10 It is clear from those tables that coating enhances mechanical properties of coated paperboard along machine direction and cross direction.Mineral pigments are functional fillers that impart specific properties to paper.

As expected coating paperboard derived from Alexandria Company by any one of three coating materials applied in this study namely $\mathrm{CP} 1, \mathrm{CP} 2$ and CP3 enhanced all mechanical properties along machine direction and cross direction. For example, stiffness was improved from 137 for

TABLE 5. Percentage of coating preparation.

\begin{tabular}{|c|c|c|c|c|c|}
\hline $\begin{array}{c}\text { Coating } \\
\text { components }\end{array}$ & Water & $\mathrm{CaCO}_{3}$ & $\mathrm{TiO}_{2}$ & Kaolin & Resin \\
\hline Coating1 & $100 \mathrm{ml}$ & $53.3 \mathrm{gm}$ & $13.3 \mathrm{gm}$ & $66.6 \mathrm{gm}$ & $60 \mathrm{gm}$ \\
\hline Coating 2 & $100 \mathrm{ml}$ & $40 \mathrm{gm}$ & $26.6 \mathrm{gm}$ & $66.6 \mathrm{gm}$ & $60 \mathrm{gm}$ \\
\hline Coating 3 & $100 \mathrm{ml}$ & $26.7 \mathrm{gm}$ & $39.9 \mathrm{gm}$ & $66,6 \mathrm{gm}$ & $60 \mathrm{gm}$ \\
\hline
\end{tabular}

TABLE 6. The measured parameter of viscosity of

\begin{tabular}{cc}
\multicolumn{2}{c}{ the applied coating pigments. } \\
\hline RPM & 200 spin \\
\hline Temp & 25 \\
\hline Torque & 14.8 \\
\hline Vis & $36.7 \mathrm{Cp}$ \\
\hline STR & $66.5 \mathrm{D} / \mathrm{cm}^{2}$ \\
\hline S Rate & $186 \quad 1 / \mathrm{sec}$ \\
\hline
\end{tabular}

Egypt. J. Chem. 60, No. 3 (2017) 
uncoated paperboard to 155 for coated one.

\section{Conclusion.}

Rice straw, the non-wood residue is found in Egypt in large quantities. Pulping rice straw by aqueous acetic acid at atmospheric pressure gave pulp with accepted properties due to the heigh silica content in pulp. The silica left in the pulp may function as a filler of paper. The acetosolve rice straw pulp was blended with recycled duplex pulp producing paperboard of basis weight $100 \mathrm{~g} / \mathrm{m}^{2}$ and $280 \mathrm{~g} / \mathrm{m} 2$. The later contains upper layer of wood pulp. Mineral pigments such as $\mathrm{Caco}_{3}$, titanium oxide and kaolin were applied to coat one surface of paperboard having $280 \mathrm{~g} / \mathrm{m}^{2}$. These pigments are functional fillers that impart specific properties to paper and satisfy the requirements of reducing the cost of production. Coating enhances mechanical properties of coated paperboard along machine direction and cross direction. The laboratory made paper sheets have lower mechanical properties than Alexandria company sheets.

TABLE 7. Effect of coating on mechanical properties of paperboard made from $10 \%$ rice straw pulp (RS30) and $90 \%$ duplex (basis weight $140 \mathrm{~g} / \mathrm{m}^{2}$ ) with top layer of wood pulp ( basis weight $140 \mathrm{~g} / \mathrm{m}^{2}$ )

\begin{tabular}{|c|c|c|c|c|c|c|}
\hline Paperboard & $\begin{array}{c}\text { MD } \\
\text { Stiffness } \\
\text { strength, } \\
\text { g.cm }\end{array}$ & $\begin{array}{c}\text { CD } \\
\text { Stiffness } \\
\text { strength, } \\
\text { g.cm }\end{array}$ & $\begin{array}{c}\text { MD Tensile } \\
\text { strength, } \\
\mathbf{N} / \mathbf{m}\end{array}$ & $\begin{array}{c}\text { CD } \\
\text { Tensile } \\
\text { strength, } \\
\mathbf{N} / \mathbf{m}\end{array}$ & $\begin{array}{c}\text { MD Breaking } \\
\text { length, m }\end{array}$ & $\begin{array}{c}\text { MD Tensile } \\
\text { index Nm/g }\end{array}$ \\
\hline RS30/D & 55 & 50 & 51.6 & 44.4 & 1172 & 78.18 \\
\hline RS30/Dc1 & 70 & 67 & 68.1 & 56.9 & 1502 & 100.14 \\
\hline RS30/Dc2 & 105 & 72 & 65.0 & 64.8 & 94.89 \\
\hline RS30/Dc3 & 147 & 92 & 64.5 & 52.4 & 1362 & 90.84 \\
\hline
\end{tabular}

TABLE 8. Effect of coating on mechanical properties of paperboard made from $10 \%$ rice straw pulp (RS40) and $90 \%$ duplex (basis weight $140 \mathrm{~g} / \mathrm{m}^{2}$ ) with top layer of wood pulp (basis weight $140 \mathrm{~g} / \mathrm{m}^{2}$ ).

\begin{tabular}{ccccccc}
\hline Paperboard & $\begin{array}{c}\text { MD Stiffness } \\
\text { strength, g.cm }\end{array}$ & $\begin{array}{c}\text { CD } \\
\text { Stiffness } \\
\text { strength, } \\
\text { g.cm }\end{array}$ & $\begin{array}{c}\text { MD Tensile } \\
\text { strength, } \\
\text { N/m }\end{array}$ & $\begin{array}{c}\text { CD } \\
\text { Tensile } \\
\text { strength, } \\
\text { N/m }\end{array}$ & $\begin{array}{c}\text { MD } \\
\text { Breaking } \\
\text { length , m }\end{array}$ & $\begin{array}{c}\text { MD Tensile } \\
\text { index, } \\
\text { Nm/g }\end{array}$ \\
\hline RS40/D & 70 & 40 & 51.4 & 47.4 & 1285 & 85.66 \\
\hline RS40/Dc1 & 105 & 42 & 66 & 65.4 & 1486 & 99.09 \\
\hline RS40/Dc2 & 115 & 50 & 56.0 & 48.9 & 1373 & 91.54 \\
\hline RS40/Dc3 & 100 & 87 & 65.8 & 48.0 & 1333 & 88.91 \\
\hline
\end{tabular}

TABLE 9. Effect of coating on mechanical properties of paperboard made from $10 \%$ rice straw pulp (RS50) and $90 \%$ duplex ( basis weight $140 \mathrm{~g} / \mathrm{m}^{2}$ ) with top layer of wood pulp ( basis weight $140 \mathrm{~g} / \mathrm{m}^{2}$ ).

\begin{tabular}{ccccccc}
\hline Paperboard & $\begin{array}{c}\text { MD Stiffness } \\
\text { strength }, \mathbf{g . c m}\end{array}$ & $\begin{array}{c}\text { CD } \\
\text { Stiffness } \\
\text { strength, } \\
\mathbf{g . c m}\end{array}$ & $\begin{array}{c}\text { MD Tensile } \\
\text { strength } \\
\mathbf{N} / \mathbf{m}\end{array}$ & $\begin{array}{c}\text { CD } \\
\text { Tensile } \\
\text { strength, } \\
\mathbf{N} / \mathbf{m}\end{array}$ & $\begin{array}{c}\text { MD } \\
\text { Breaking } \\
\text { length, m }\end{array}$ & $\begin{array}{c}\text { MD } \\
\text { Tensile } \\
\text { index, } \\
\mathbf{N m} / \mathbf{g}\end{array}$ \\
\hline RS50/D & 70 & 37 & 49.8 & 47.3 & 1185 & 79.04 \\
\hline RS50/Dc1 & 100 & 65 & 65.8 & 45.9 & 1390 & 92.67 \\
\hline RS50/Dc2 & 105 & 82 & 58.6 & 49.1 & 1229 & 81.95 \\
\hline RS50/Dc3 & 127 & 90 & 60.1 & 53.7 & 1234 & 82.32 \\
\hline
\end{tabular}


TABLE 10. Effect of coating on mechanical properties for Alexandria paperboard

\begin{tabular}{ccccccc}
\hline Paperboard & $\begin{array}{c}\text { MD } \\
\text { Stiffness } \\
\text { strength, } \\
\text { g.cm }\end{array}$ & $\begin{array}{c}\text { CD } \\
\text { Stiffness } \\
\text { strength, } \\
\text { g.cm }\end{array}$ & $\begin{array}{c}\text { MD Tensile } \\
\text { strength } \\
\mathbf{N} / \mathbf{m}\end{array}$ & $\begin{array}{c}\text { CD } \\
\text { Tensile } \\
\text { strength, } \\
\mathbf{N} / \mathbf{m}\end{array}$ & $\begin{array}{c}\text { MD Breaking } \\
\text { length, } \mathbf{m}\end{array}$ & $\begin{array}{c}\text { MD Tensile } \\
\text { index } \\
\text { Nm/g }\end{array}$ \\
\hline UP & 137 & 55 & 62.1 & 31.7 & 1592 & 106.15 \\
\hline CP1 & 152 & 75 & 111 & 37.3 & 2685 & 179.03 \\
\hline CP2 & 155 & 40 & 104.3 & 35.8 & 2536 & 169.59 \\
\hline CP3 & 147 & 45 & 109.8 & 38.8 & 2574 & 172.91 \\
\hline
\end{tabular}

\section{References}

1. Tripathi S., Singh S., Gangwar A., Mishra O. P., Chakrabarti S. K., Bhardwaj N. K. \& Varadhan R. Blending of banana stem with wheat straw and bagasse to enhance physical strength properties of paper. Indian Pulp and Paper Technical Association, 121-128 (2013).

2. Alejandro R., Ana M., Luis S., Jalel L. and Luis J., . Rice straw pulp obtained by using various methods, Bioresource Technology (99), 2881-2886 (2008).

3. Nassar M. A. ,Hassan M. A.M., El Sahkawy M., and Yussuf H. R. An optimum mixture of virgin rice straw pulp and recycled old newsprint (ONP) pulp and their antimicrobial activity, International Journal Of Technology, 63-72 (2015),.

4. Dereca W., Md. Nuruddin, Mahesh H. , Alfred T-N., Shaik J., Extraction and characterization of lignin from different biomass resources, Journal of Materials Research and Technologyvolum 4, 26-32 (2015)

5 Pauly H., Foulon A., Hansen O., Haberstroh O., Bailom H. and Sextl J. ,Scheidungvonligninkomponenten. Berichte der Deutschen Chemischen Gesellschaft 67, 1177-1199 (1943).

6. Jahan M.S., Chowdhury, D. , Islam M. K., Atmospheric formic acid pulping and TCF bleaching of dhaincha (Sesbaniaaculeata), kash (Saccharumspontaneum) and banana stem (Musa Cavendish), Industrial Crops and Products, 26 (3), 324-331 (2007),

7. Jahan, M.S., Lee, Z.Z., Jin, Y.,., Organic acid pulping of rice straw, part-I: cooking. The Turkish Journal of Agriculture \& Forestry, 30 (3), 231-239 (2006)

8. Yang L., Wei L., Qingxi H., Song H., Yang W., and Dandan Z. Release of acetic acid and its effect on the dissolution of carbohydrates in the autohydrolysis pretreatment of poplar prior to chemi-thermomechanical pulping, Industrial \& Engineering Chemistry Research.,53(20),8366-8371 (2014),

9. Levlin J.and Söderhjelm L.; Pulp and paper testing; Papermaking Science And Technology Encyclopedia 17, FapetOy; Helsink (2000),

10. Ibrahim S.,RefaatY. and Nassar M., , Synthesis and characterization of nanostructured Polystyrene/ polybutylacrylate copolymer coating, Egyption Journal of Chemistry, 58,5.(2015)

11. Edwards. R., In Extrusion Coating Manual, 4th edition, (T. Bezigian, Ed.), Tappi Press, Atlanta pp. 173-179(1999)

12. Biermann, C. J., (1996). Hand Book of Pulping and Papermaking. Elsevier Science \& Technology Books, p.754

13. Rousu P., and Anttila J., , Sustainable pulp production from agricultural waste. Resources Conservation and Recycling; 35, 85-103 (2002).

14. Lundquist K. and Hedlund K., Acid degradation of lignin. Part I. The formation of Ketones of the Guaiacylpropane series. Actachemicascandinavica. 21 (7), 1750-1754 (1967).

15. Lundquist K., Low molecular weight lignin hydrolysis products. Applied Polymer Symposia Series. 28, 1393-1407 (1976).

16. Jahan M. S., Chowdhury D. A. N., and Islam M. K., (2014).Characterization of lignin isolated from some nonwood available in Bangladesh, Bioresource Technology 98, 465-469

17. Jeon S.J., and Bousfield D.W, Print gloss Egypt. J. Chem. 60, No. 3 (2017) 
development with controlled coating structures,

Journal of Pulp and Paper Science. 30 (4), 90-96

(2004)

(Received 21/9/2016;

Accepted 19/4/2017)

\section{تحسين الأداء للكرتون المصنع محليا}

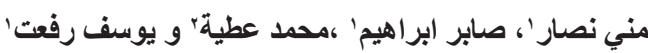

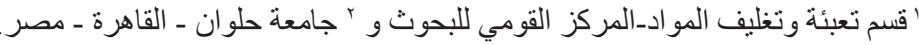

تتجه الصناعة في الوقت الحالي إلى توفير ورق الكرتون المستخدم في أغر اض التعبئة بحيث يتمتع بخو اص ميكانيكية

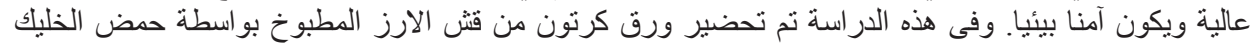

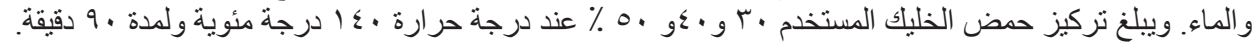

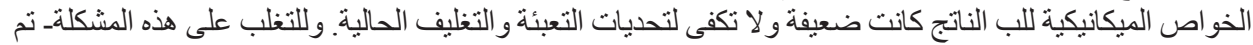

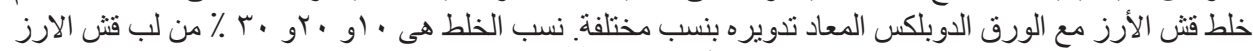

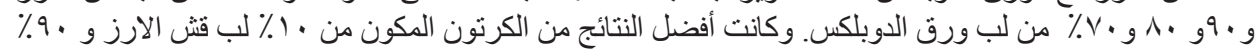

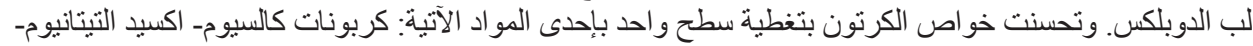
الكاولين. وقد أدت هاتان المعالجتان (الخلطو التغطية) إلى تحسين خو اص الكرن الكرنون الناتج من قش الأرز في كلا الاتجاهين. 